\title{
The Finno-Ugric foundations of language teaching
}

\author{
JOHANNA LAAKSO \\ Universität Wien
}

\begin{abstract}
The aim of this paper is to explore the relationship of Finno-Ugric studies and language teaching: What can the FinnoUgric inheritance or relatedness mean in the practice of teaching and learning Finno-Ugric languages as a second or foreign language? Beyond the background knowledge which is typically incorporated in the academic teaching of the Finno-Ugric languages, questions of the history and relatedness of these languages may surface in connection with two aspects. First, the teaching of the rich and complex morphology and, in particular, morphophonology might profit from excursions into the (pre)history of the language. Second, Finno-Ugric languages are often "othered", seen as "something different" and contrasted with major (Indo-) European languages. This fact, although it may play a crucial role for the recruitment and motivation of the students, has - like aspects of identity in general - often been ignored in the study of language teaching.
\end{abstract}

Keywords: Finno-Ugric languages; historical linguistics; language teaching; language relatedness; motivation; sociology of learning

\section{Preamble: Defining the points of departure}

To answer the question of the relationship between Finno-Ugric studies and language teaching, we should first define the concept of Finno-Ugric studies. As we all know, this is an almost impossible task. Around the 
hard core of the research into the only thing which can uncontroversially be called "Finno-Ugric", that is, research into the relatedness and common heritage of the Finno-Ugric languages, in other words, historical linguistics, there are closely and more distantly related fields of research, the "Finno-Ugrianness" of which is a question of traditions, definitions, institutions and resources. Most of us might agree that research into the metaphors of Ob-Ugric bear songs is pretty close to what is considered traditional hard-core Finno-Ugristics, but whether research into the metaphors in the Helsinki slang belongs to Finno-Ugristics is a trickier question. And how about the use of metaphors in a Finnish or Hungarian learner's meta-language?

The relatedness of the Finno-Ugric languages constitutes the foundation of Finno-Ugric studies as a discipline. But can there be a common foundation for the teaching of the Finno-Ugric languages - beyond the role of Finno-Ugric studies as an "operational environment", provider of data and points of comparison for applied linguistics (Suni 2012)? In other words, does the fact that Hungarian and Mari belong to the Finno-Ugric language family play any role for the teaching of Hungarian or Mari as a foreign language? Or can the traditional hard core area of Finno-Ugrian studies, historical linguistics, contribute anything to the teaching of a language like Hungarian or a language like Mari?

To answer these questions, we will have to take a closer look at the Finno-Ugric inheritance in today's Finno-Ugric languages from a didactic point of view: the rich morphology, the fundamental differences in the lexicon, perhaps also certain non-SAE features of the syntax. But before that, there are two other aspects that deserve to be dealt with. They are not exclusively characteristic of Finno-Ugric languages only, and they may not be typical of all teaching contexts of all Finno-Ugric languages, but they often surface in popular discourses about the teaching and learning of these languages, and they are of great importance for the native speakers of Finno-Ugric languages as well, for their identity and for how they conceptualize a speaker - native or nonnative - of their language. These two aspects are (i) otherness - being different, being seen 
from the point of view of another language or culture, and (ii) minority position: being in a subordinate, disadvantaged position, or at least being a "less widely used and studied language".

The latter also implies a "one-way" bilingualism. For all Finno-Ugric and many other minorities, bilingualism is a rule. This means that functional or even (near-)native command of the majority language is regarded as something self-evident (for instance, every Sámi speaker in Finland is bilingual in Finnish). However, for members of the majority (for instance, for Finns or Norwegians in Lapland or Russians in Udmurtia), learning a Finno-Ugric minority language is not something that can be automatically expected. Minority languages may even be socially stigmatised so that, for instance, foreigners who attend a summer course of Mari in Mari $\mathrm{El}$ are met with astonishment, (to quote a student from Vienna) "as if somebody would come to Hungary to learn the Roma language".

But, in fact, a similar one-way requirement is also very real for any speaker of a "minor" language like Finnish or Hungarian. While British or US citizens can graduate from a university as monolingual English speakers, for any Finnish school child of today learning English (and perhaps some other languages as well) is natural and self-evident - and thus, many Finns (and probably Hungarians and Estonians as well) find it difficult to understand why a foreigner would want to learn their language, and many of them tend to switch to English as soon as they spot a foreign accent (as many foreign students of Finnish in Finland, at least, have experienced). Finns seem to have a low tolerance in general towards non-native Finnish (deviations which in the mouth of native speakers might count as dialectalisms or word play are often explicitly corrected), and this will be a real challenge for the integration of migrants in Finland (see also Korhonen 2012). According to the experiences of many friends and colleagues of mine, the situation might be similar in Hungary: communicating with fluent non-native speakers seems to be strange for many Hungarians and provoke harsh-sounding reactions to alleged mistakes or incorrect forms. However, there is obviously very little solid research on this question so far. 


\section{The learner of a Finno-Ugric language - in his/her own eyes ...}

These two aspects of identity are also crucial for students' choices: the recruitment of students and their motivation to learn a language which is often perceived as something fundamentally different from anything else. Sometimes, this fundamental otherness even explicitly constitutes the motivation for learning a Finno-Ugric language. Many students of Finnish or Hungarian in other countries have found their way to this language simply because this language is "different": academic curricula of linguistics in the Western world often include courses in a non-IndoEuropean language.

The "otherness" of the Finno-Ugric languages is often highlighted even in textbooks which may begin with statements of this kind (an example from Leila White's (2006) Finnish grammar; similar "excuses" can probably be found in textbooks and grammars of very many non-Indo-European languages):

Finnish is a different kind of language.

Teaching Finnish for foreigners, I have heard students ask impatiently a thousand times: "Why is Finnish such a difficult language?" It is easy to answer the question in the words of the title: "Because Finnish is a different kind of language."

Almost all languages of Europe are related to one another, being members of the Indo-European language family. Finnish however belongs to the Uralic languages [---]

Finnish has been influenced in many ways throughout its history by Indo-European languages [---] The structure of Finnish however differs considerably from that of Indo-European languages. Even the vocabulary is largely original [---]

What is different?

Finnish has no articles (cf. English $a$, the), and the words have no gender [---] Finnish words acquire grammatical forms by using endings, or suffixes. The Indo-European languages [sic!] express the same thing by using separate words [---] (White 2006: 12-13) 
However, the question of why somebody wants to learn a "different" language and how s/he sees herself/himself as a learner of this language and whether the problems behind the "impatient questions" of students can be overcome simply by explaining that "well, Finnish is different" is seldom explicitly dealt with in the existing literature about teaching and learning Finno-Ugric languages. In fact, the problem is of a more general kind.

Motivation in language learning is a pretty intensively researched question complex (see e.g. Gardner 1985; Ames 1992; Dörnyei \& Ottó 1998); there are also studies of motivation in the learning of Finno-Ugric languages as a second/foreign language, see e.g. Alatalo (2005). Numerous different approaches are possible, but it might be stated, very crudely, that from the earlier socio-psychologically conditioned views on motivation the focus of research is shifting to individual psychology and cognition, to classroom settings and also to monocultural environments - that is, to foreign language, not second language acquisition (Dörnyei 1998: 125). It has become obvious that the desire for contact and identification with the speakers of the target language is not a fundamental factor for learning motivation but only has relevance in some specific contexts (Noels et al. 2000) - that is, not all language learners study a language in order to become members of a speaker community, and this seems to apply even stronger for many learners of Finno-Ugric languages.

At the same time, sociologically oriented researchers can state that questions of identity in second language acquisition research - how the language learner sees herself/himself and her/his role between speaker communities, and how this affects the language learning process - were hardly dealt with in SLA research before the turn of the millennium. To quote Block (2007: 869):

[---] there have, in fact, been far fewer studies of identity in FL settings than there have been studies situated in naturalistic settings. When such studies have been published, they have tended to focus on transformations in individuals as language learners. However, these documented transformations have not revolved around the native 
speaker-nonnative speaker dichotomy [---]; rather, they have been about learners taking greater control over their learning [---].

In the last few years, however, poststructuralist approaches to identity research have shed light on new questions. Block (2007: $865 \mathrm{ff}$ ) points out some of these. First, language learning is now regarded not just as a cognitive but also as a social process, during which the learner gains entry into a community of practice by way of "legitimate peripheral participation". Within this approach, SLA researchers can, for example, investigate learner biographies or new forms of participation such as interaction in virtual social communities.

Second, poststructuralist research regards identity as something fluid, not a fixed product but a process connected with negotiations and struggles. This means paying attention to complicated interactions between social factors such as gender, class or race. But, as Mervyn Bendle (2002, quoted in Block 2007: 873) argues in his criticism of poststructuralist identity research, it may also imply a shift "from overly optimistic and romanticized approaches to identity as a self-made project, to more pessimistic and dark ones". That is: when constructing her/ his learner's identity, the language learner is not only subject to diverse group pressures, expectations, teaching traditions etc., but dark subconscious factors will play a role as well. You cannot just choose an optimistic easy-going attitude towards learning a new language and simply decide to "take greater control over your learning"; how you learn a language depends on your personality, your previous experiences, your expectations etc. - factors you cannot always control or even notice.

It is impossible to sum up the variety of prevailing ideas about identity and motivation in language learning - what I have just presented has just scratched the surface. In fact, we still know all too little about second language acquisition; for instance, the Common European Framework of Reference does not base itself on any specific theory or model of language learning, "because there is no sufficiently strong research-based consensus on how learners learn" (Jaakkola 2000: 6). But considering the relevance of identity, motivation or attitude specifically from the point of 
view of Finno-Ugric languages, the diversity and complexity of the phenomenon are important. Whatever theory or model is applied, it should be able to account for different motivations, in particular, the variety of individual or "instrumental" orientations.

In particular, I would like to highlight the more or less unexplored effects of perceived difference and prejudices about the strangeness and difficulty of a Finno-Ugric target language. Of course, there is a plethora of research on how language learning is affected by perceived similarity or relatedness (see, for instance, Muikku-Werner et al. 2014; De Angelis \& Selinker 2001; Williams \& Hammarberg 1998), or on transfer effects in grammar (how the features of the native language are reflected in the learner's metalanguage; Falk \& Bardel 2010). However, it might be interesting to investigate how the presumptions about a language being "exceptionally difficult" or "one of the most difficult European languages to learn" affect the outcome of language learning. The myth of Hungarian, Finnish and Estonian being exceptionally difficult or even impossible to learn is cherished by outsiders and by these nations as well. Together with the attitudes of native speakers - probably less tolerance towards non-native speakers than with languages that are frequently used as lingue franche - this may constitute a major obstacle for learning these languages, but there seems to be very little solid research in these questions, beyond the stereotypical encouraging words of language teaching professionals: "Hungarian/Finnish/Estonian is not difficult, it's just different.”

\section{... and as a "remote participant?"}

To return to the social aspects of a language learner's role: as mentioned before, new approaches to communication and knowledge, challenging the traditional ideals of "depersonalised" scientific objectivity and highlighting the "situated" character of knowledge, connected with personal features such as gender, class or race, have shifted the focus. Learning is now investigated not only as a cognitive process, of internalising 
knowledge, but also as a social process. As knowledge is socially constituted, the knowledge and meanings to be internalised are socially negotiated, by way of participation in communities of practice. In other words, a language learner is "initiated" into a community.

In connection with this, the question arises whether the final goal in the teaching of a Finno-Ugric language is to make the student a more or less full member, an accepted speaker of the target language. This might be a relevant goal in some cases - there are students who really want to be able to live and work in a Hungarian-, Finnish- or Estonian-speaking community - but not for all students or contexts. The minor FinnoUgric languages are typically studied for academic or private interests only, but so are, in some cases, the major Finno-Ugric languages as well. Often the teaching groups are very heterogeneous, as concerns the backgrounds and motivations of the students. Some come with a diffuse and holistic interest in anything connected with the target language and the culture and history of its speakers (cf. e.g. Patri 1996), some have specifically linguistic motives. The former type, the "holistic" interest, is also highlighted in some traditions and institutions such as the teaching of Hungarian (Studies) abroad - the teaching of Hungarian (far more than Finnish, for instance) is typically seen as part of a complex discipline (hungarológia, magyarságtudomány; cf. e.g. Giay 1998; Kovács 2008). This type of motivation is probably easier to "sell" to prospective students, to policy-makers and institutions: contributing to intercultural communication and international understanding are noble goals which also have a prominent place in European language and education policies.

The way to full membership is supposed to lead through a stage of "legitimate peripheral participation"; however, the transition from apprenticeship to full membership is not always smooth or problemfree, and the problems of learners who remain excluded from full participation have not been sufficiently dealt with in the sociology of learning so far (Lea 2005: 184). Lea (2005) claims that this is a problem concerning higher education in general, while in language teaching specifically, 
the problems of advanced learners seem to be more prone to be marginalised. As for Finnish, there has been some research on the specific problems of advanced learners (Siitonen 1999 etc.), and this question is gaining more and more attention in connection with the integration of immigrants in Finland, where children of migrant families are challenging the traditional goals of Finnish language teaching at schools (see e.g. Kalliokoski 2008: 355; Suni \& Latomaa 2012); in Estonia, there is a small but growing body of research concentrating on the problems of advanced learners (e.g. Pool 2007), but the problems dealt with pertain more to the grammar of the target language than to language-sociological factors or language teaching. For the minor Finno-Ugric languages, acquiring near-native proficiency and acceptance in the speaker community has probably very little to do with institutionalised language teaching (as far as these languages are learnt by outsiders to that extent, it probably happens in the family sphere, typically in connection with mixed marriages). In any case, there is probably very little research on these aspects - and the situation may change, if the emancipation of minority languages makes language studies more attractive for "outsiders" as well.

An even more problematic question concerns the postulated "community of practice" itself. James Paul Gee (2005) points out that this notion gives rise to several problems, as there are no clear criteria for either "community" or "membership". (For instance: Are Janie, who is an active, hard-working student, and her classmate Johnny, who is just "playing the game" for a passing grade, members of the same community of practice of learners, or do they belong to two different communities?) Instead, he proposes the notion of "semiotic social spaces": these have a content (they are "about" something), an internal grammar (a design of its content; in the case of language learning, this might be the grammar of the target language in the wide sense) and an external grammar (an emergent design constructed by the actions of its participants), plus one or more portals for entrance and interaction. A particular type of semiotic social spaces are "affinity spaces", which Gee exemplifies with the real-time strategy computer game Age of Mythology and the virtual 
community of its users. Affinity spaces are based on common endeavour, they typically have flat or unclear hierarchies and favour diffuse and dispersed constructions of status and knowledge (for instance, dispersed knowledge - by this Gee means that affinity spaces encourage the use of knowledge which is present elsewhere, for example outside the classroom).

Considering the variety of contexts and motivations in teaching and learning Finno-Ugric languages, the notion of affinity space seems fruitful enough. Of course, migrants in Finland, who struggle to learn the language well enough to be accepted in Finnish society as speakers of Finnish, are clear cases of participants-to-be in a community of practice. But university students in other countries who want to learn Hungarian, Finnish, Estonian or a minor Finno-Ugric language for private or academic interests do not necessarily form a community of practice nor aspire to be members of a speaker community in the traditional sense. Instead, they are united by common endeavour (while traditional social factors such as class, gender or age are backgrounded), there are many different routes to participation or to status, and no hierarchic leadership - that is, the teaching of Estonian in Paris or Mansi in Vienna might be described in Gee's terms as an affinity space. My final question to language teaching professionals: How about presenting the learning of this exotic Finno-Ugric language more like a virtual game community, highlighting the common endeavour aspect - instead of highlighting the (often fictitious) goal of becoming a member in a real speaker community? If we regard the learning of Finno-Ugric languages as an affinity space, could it help us construct virtual community portals for language learners and a more powerful and more helpful Internet presence?

\section{The Finno-Ugric legacy}

What, then, is Finno-Ugric in these exotic languages that even some outsiders, for their various and sometimes bizarre reasons, want to learn? I took a quick look at some textbooks and grammars of Finnish, 
Hungarian and Estonian to see what is explicitly told about this FinnoUgric legacy, and the outcome was fairly meagre. The "excuse" in Leila White's grammar is illustrative of the situation: if the Finno-Ugric background is mentioned at all, then just as a synonym for the language being different. When it comes to listing actual "different" features, they often have very little to do with the Finno-Ugric relatedness, nor are the connections of these features with the Finno-Ugric legacy ever explained in more detail. For example, most Finno-Ugric languages lack articles, but so do many other languages as well. Or, White's statement that where Finnish has suffixal inflection, "the Indo-European languages" use separate grammatical words is slightly misleading (if not patently false), as anybody who has studied Indo-European languages such as Latin can testify.

In many introductions in textbooks, encyclopedias or on (serious) websites about languages and linguistics, the large number of cases in the Finno-Ugric languages occupies a prominent position. According to my own experiences, many educated non-linguists in Central and Western Europe are well aware of this (Mein Gott! Fünfzehn Fälle!) and connect the large number of cases with the popular myth of these languages being impossible to learn, sometimes with the obvious implication that it is precisely the heavy case system that makes these languages so notoriously difficult. Now case inflection, although almost lost in many Western European languages, is not completely unknown to educated Europeans who have studied languages like Latin. The same goes for some other categories of morphology which are not exotic at all, such as person, number or tense - here, most Finno-Ugric languages behave similarly to their IE neighbours. Other categories, in contrast, such as possessive suffixes, or the object conjugation in Hungarian, are obviously all too exotic to act as a foundation for a "language myth" (cf. Bauer \& Trudgill 1998). Besides missing the point, in a probably very typical way, the myth of the difficult heavy case system is based on a factoid: all mainstream reconstructions of the PFU/PU case system only have 5-6 cases, and heavy case systems such as in Finnic or Hungarian 
are largely due to more recent grammaticalisation. (And, by the way, Spencer (2008) has argued for an alternative analysis in which Hungarian does not have a case system at all, just "fused postpositions".)

In general, it is obvious that the rich morphology of the Finno-Ugric languages challenges the learner, especially students who have earlier only studied languages like English. As we all know, it may be very frustrating that you cannot form a simple sentence without having to inflect everything in case or person and number - or even, as a teacher of Hungarian once put it, "if we start with the subjective conjugation only, the students will feel like in a museum during the first weeks - they can go everywhere but cannot touch, take or do anything". But the main problem is probably not in the richness of the morphology itself but in the students' attitudes and expectations. Hannele Branch [s.a.] writes, speaking from a long experience as a lecturer of Finnish in Britain: "Students often believe, or expect, that a language can be learnt by osmosis - just like that, in the classroom." And when these students are unpleasantly surprised by the amounts of grammar they are supposed to learn, then the facts of the Finno-Ugric legacy in their target language are far less relevant than what they believe this Finno-Ugric background to mean.

As one central characteristic of (the major) Finno-Ugric languages, introductions and encyclopedia articles often mention the agglutinative character. Obviously the traditional "macrotypology" (the division of the world's languages into agglutinative, fusional, isolating and polysynthetic types) is still very popular, probably because of its great heuristic value. Yet, as we all know, no Finno-Ugric language is an ideal example of the agglutinative type, and Estonian and Sámi in particular are already pretty far from it (although there are typological cross-currents and the "fusional" character of Estonian is often exaggerated in literature, cf. Grünthal 2000). Calling the Finno-Ugric languages "agglutinative" probably helps students get prepared for a lot of inflectional forms and for long words which may contain long chains of suffixes (technically, it might be more appropriate to speak of "high degree of synthesis"). But it will not help students understand morphophonology, such as 
stem vowel or stem type alternations in Hungarian or consonant gradation in Finnic, and if the students are well versed in linguistic typology, their expectations may be geared in the wrong direction. In practice, at least students of Finnish or Estonian will end up memorising "theme forms" of central inflection types, putting up with the fact that you cannot always correctly predict the inflected form on the basis of the stem or the nominative (that is, if you haven't memorised the inflection type as well), and finding consolation in statements like this famous one about Estonian: "No language can be totally evil if it has a special inflection class just for the word for 'beer"'

Finally, according to the experience of many teachers (see e.g. Branch [s.a.], and also according to my own experience from learning Hungarian) the real obstacle for the learning of languages like Hungarian, Finnish or Estonian is not the grammar - after all, grammars are structured systems and can be learned in terms of interdependent rules - but the vocabulary. There is no way to escape the hard work of memorising words whose cognates may be unknown and forms difficult to predict. And this applies, even if you happen to know the original of a loanword or the cognate of a Hungarian word in Finnish - etymological knowledge may add your learning motivation but its effect to the outcome will be indirect even at its best. Knowledge of the Finno-Ugric legacy will not take you very far: the ancient inherited words are few, they may belong to semantic fields which are not very central for today's language learners, they may have been marginalised or almost forgotten in today's language, or - especially if they are central and frequent words - they may display irregularities and/or particularly complex morphophonological alternations or suppletion. Besides, most difficulties or differences in the vocabulary have little to do with Finno-Ugric relatedness in the strict sense: many "exotic" words are possible substratum words without a proper etymology, loanwords from a language which Western learners of the Finno-Ugric languages normally do not know, or loanwords too well adapted to be recognisable - or even products of a puristic language reform. 


\section{Conclusion}

There is very little research on how the awareness of distant relatedness or the knowledge of the history or prehistory of the target language really affects your learning. Effects of relatedness between Finnish and Estonian, of course, have been investigated, and there are some studies on the use of historical linguistics in classical cases such as the French orthography (Arteaga \& Herschensohn 1995). To a certain extent, knowledge of the historical background may be useful in making morphophonological alternations understandable. (In her recent MA thesis, Triinu Viilukas (2010) has shown that explaining the principles of consonant gradation in Estonian helps students and adds their motivation - despite the fashionable emphasis on intercultural communication, many students also want and need grammar and rules, even if only as a moral support: there is a system somewhere out there, not just a chaos of very different inflection forms.) However, the Finno-Ugric background as a whole is probably less important than certain languagespecific parts of historical phonology or etymology (for instance, the principles of word structure underlying the consonant gradation in Finnic and Sámi, or the history of individual loanword strata in a certain language).

Moreover, applying historical linguistics in second/foreign language teaching has certain obstacles which are particularly relevant in the case of Finno-Ugric languages. First of all, applying formal linguistic knowledge requires language awareness, an ability to analyse and discern patterns and structures in one's own language as well. Surprisingly enough, formal language teaching at school does not necessarily prepare students for this - for instance, Csire (2008; Csire \& Laakso 2009) points out that despite having learnt not only German grammar but also English, French and Latin at school, heritage-language speakers of Hungarian in Austria are often strikingly unable to analyse grammatical categories in Hungarian (for instance, to distinguish between the similar-sounding suffixes for accusative case and past tense). 
Second, the learners of Finno-Ugric languages are a very heterogeneous group with heterogeneous backgrounds and motivations. While many students around the world study these languages for academic purposes and would profit from purely linguistic resources which do not exist so far (such as a proper linguistic introduction into Finnish or Finnic or Uralic in general, or an up-to-date historical grammar of Finnish in some accessible language), there is a growing number of language learners (in particular, migrants in Finland and Estonia) with very practical or personal motives and little interest in linguistics or "grammar". Obviously, the Finno-Ugric background of the target language is far more relevant for the former type of learners. Perhaps due to the small volume of teaching and the scarcity of resources, there are very little diversified teaching materials available - that is, the textbooks available must be used for a very broad audience, from half-literate immigrants to professional linguists.

Finally, it seems that there is very little research so far on the image of the Finno-Ugric languages. How are these languages portrayed? Is it really so that the myth of the Finno-Ugric languages as something impenetrable and impossible to learn is cherished by both outsiders and by speakers of the (major) Finno-Ugric languages themselves? And if it is so, what could we do to change the state of affairs?

\section{References}

Alatalo, Susanna 2005. Wienin yliopiston suomen kielen opiskelijoiden oppimismotivaatio. ['Learning motivation of students of Finnish at the university of Vienna.'] MA thesis, University of Jyväskylä. http://urn.fi/ URN:NBN:fi:jyu-2005238 (15.7.2010).

Ames, Carole 1992. Classrooms: Goals, structures and student motivation. Journal of Educational Psychology 84 (3), 261-271. http://dx.doi. org/10.1037/0022-0663.84.3.261

Arteaga, Deborah L., Julia Herschensohn 1995. Using diachronic linguistics in the language classroom. - The Modern Language Journal 79 (2), 212-222. http://dx.doi.org/10.1111/j.1540-4781.1995.tb05432.x 
Bauer, Laurie, Peter Trudgill (Eds.) 1998. Language Myths. London: Penguin Books.

Bendle, Mervyn F. 2002. The crisis of identity in high modernity. - British Journal of Sociology 53 (1), 1-18. http://dx.doi.org/10.1080/00071310120109302

Block, David 2007. The rise of identity in SLA research, post Firth and Wagner (1997). - The Modern Language Journal 91 (s1), 863-876. http://dx.doi. org/10.1111/j.1540-4781.2007.00674.x

Branch, Hannele [s.a.]. Is Finnish a difficult language? http://finland.fi/public/ default.aspx? contentid=160057 (22.7.2010).

Csire, Márta 2008. Ungarisch-deutsche Zweisprachige im Sprachunterricht: Über die Problematik einer speziellen Zielgruppe. - Johanna Laakso (Ed.). Ungarischunterricht in Österreich $=$ Teaching Hungarian in Austria. Finno-Ugrian Studies in Austria 6. Wien: LIT Verlag, 139-153.

Csire, Márta, Johanna Laakso 2009. Teaching the Heritage Language as a Foreign Language: On the Questions of Bilingualism and Minority Language Teaching in Austria. - Paper presented at the XII ICML Conference in Tartu, May 2009.

De Angelis, G., L. Selinker 2001. Interlanguage transfer and competing linguistic systems in the multilingual mind. - J. Cenoz, B. Hufeisen, U. Jessner (Eds.). Cross-linguistic Influence in Third Language Acquisition: Psycholinguistic Perspectives. Clevedon: Multilingual Matters, 42-58.

Dörnyei, Zoltán 1998. Motivation in second and foreign language learning. - Language Teaching 31 (3), 117-135. http://dx.doi.org/10.1017/ S026144480001315X

Dörnyei, Zoltán, István Ottó 1998. Motivation in action: A process model of L2 motivation. - Working Papers in Applied Linguistics 4, 43-69.

Falk, Ylva, Camilla Bardel 2010. The study of the role of the background languages in third language acquisition. The state of the art. - IRAL. International Review of Applied Linguistics in Language Teaching 48 (2-3), 185-219. http://dx.doi.org/10.1515/iral.2010.009

Gardner, Robert C. 1985. Social Psychology and Second Language Learning: The Role of Attitude and Motivation. London: Edward Arnold.

Gee, James Paul 2005. Semiotic social spaces and affinity spaces: From the age of mythology' to today's schools. - David Barton, Karin Tusting (Eds.). Beyond Communities of Practice: Language, Power, and Social Context. Cambridge: Cambridge University Press, 214-232.

Giay Béla 1998. A hungarológia fogalma. ['The concept of Hungarology.] - Giay Béla, Orsolya Nádor (Eds.). Magyar mint idegen nyelv. Hungarológia. 
Tankönyv és szöveggyüjtemény. Budapest, 7-17. http://mek.oszk. hu/01700/01702/index.phtml (18.7.2010).

Grünthal, Riho 2000. Typological characteristics of the Finnic languages: A reappraisal. - Johanna Laakso (Ed.). Facing Finnic: Some Challenges to Historical and Contact Linguistics. Helsinki: Helsingin yliopisto, suomalais-ugrilainen laitos, 31-63.

Jaakkola, Hanna 2000. How to Promote Learning to Learn the First Foreign Language: Piloting the Common European Framework of Reference in Finnish Schools. Research Report 215. Helsinki: University of Helsinki, Dept. of Teacher Education.

Kalliokoski, Jyrki 2008. Suomi toisena kielenä ja koulussa kirjoittaminen. ['Finnish as a second language and writing at school.] - Sara Routarinne, Tuula Uusi-Hallila (Eds.). Nuoret kielikuvassa. Kouluikäisten kieli 2000-luvulla. Tietolipas 200. Helsinki: Suomalaisen Kirjallisuuden Seura, 349-370.

Korhonen, Seija 2002. Oppijoiden suomi: Koulutettujen aikuisten käsitykset ja kompetenssit. ['Perceptions and competences of adult learners of Finnish.'] Kielikeskuksen julkaisuja 3. Helsinki: University of Helsinki.

Kovács, Magdolna 2008. History of Hungarian studies: Theory and practice. Johanna Laakso (Ed.). Ungarischunterricht in Österreich / Teaching Hungarian in Austria. Berlin: LIT Verlag, 212-227.

Lea, Mary R. 2005. 'Communities of Practice' in higher education: Useful heuristic or educational model? - David Barton, Karin Tusting (Eds.). Beyond Communities of Practice: Language, Power, and Social Context. Cambridge: Cambridge University Press, 180-197.

Muikku-Werner, Pirkko, Annekatrin Kaivapalu, Hanna-Ilona Härmävaara, Maisa Martin, Håkan Ringbom 2014. Receptive multilingualism: Mutual intelligibility of closely related languages (REMU). - On the Border of Language and Dialect. FINKA Symposium 4-6 June, 2014. Joensuu: University of Eastern Finland, 63-64.

Noels, Kimberly A., Luc G. Pelletier, Richard Clément, Robert J. Vallerand 2000. Why are you learning a second language? Motivational orientations and self-determination theory. - Language Learning 50 (1), 57-85. http:// dx.doi.org/10.1111/0023-8333.00111

Patri, Kai Hendrik 1996. Finnougristik als Studienfach: wie eng, wie weit? - Heikki Leskinen, Tõnu Seilenthal (Eds.). Congressus Octavus Internationalis Fenno-Ugristarum VIII. Jyväskylä, 58-59.

Pool, Raili 2007. Eesti keele teise keelena omandamise seaduspärasusi täis- ja osasihitise näitel. ['The acquisition of total and partial objects by learners 
of Estonian as a second language.'] Dissertationes philologicae Estonicae Universitatis Tartuensis 19. Tartu: Tartu Ülikooli Kirjastus. http://hdl.handle.net/10062/2237 (13.7.2010).

Siitonen, Kirsti 1999. Agenttia etsimässä. U-verbijohdokset edistyneen suomenoppijan ongelmana. ['In Search of an Agent. U-verb Derivations and Advanced Students of Finnish.'] Suomalaisen ja yleisen kielitieteen laitoksen julkaisuja 63. Turku: Turun yliopisto.

Spencer, Andrew 2008. Does Hungarian have a case system? - Greville G. Corbett, Michael Noonan (Eds.). Case and Grammatical Relations: Studies in Honor of Bernard Comrie. Typological Studies in Language 81. Amsterdam-Philadelphia: John Benjamins, 35-56.

Suni, Minna 2012. The impact of Finno-Ugric languages in second language research: Looking back and setting goals. - Lähivõrdlusi. Lähivertailuja 22, 407-438. http://dx.doi.org/10.5128/LV22.14

Suni, Minna, Sirkku Latomaa 2012. Dealing with increasing linguistic diversity in schools - the Finnish example. - Jan Blommaert, Sirpa Leppänen, Päivi Pahta, Tiina Räisänen (Eds.). Dangerous Multilingualism: Northern Perspectives on Order, Purity and Normality. New York: Palgrave Macmillan, 67-95.

Viilukas, Triinu 2010. Eesti keel võõrkeelena ja astmevaheldus algkursusel ehk astmete vahel udus. ['Estnisch als Fremdsprache, Stufenwechsel in den Lehrbüchern.'] MA thesis. University of Vienna.

White, Leila 2006. A Grammar Book of Finnish. Helsinki: Finn Lectura.

Williams, Sarah, Bjorn Hammarberg 1998. Language switches in L3 production: Implications for a polyglot speaking model. - Applied Linguistics 19 (3), 295-333. http://dx.doi.org/10.1093/applin/19.3.295 


\title{
Soome-ugri keelte päritolu ja sugulus keeleõppes
}

\author{
JOHANNA LAAKSO \\ Viini Ülikool
}

Käesolevas artiklis vaadeldakse soome-ugri keeleteaduse ja soome-ugri keeleõppe suhet. Mida, kui üldse midagi, tähendab keele soome-ugri päritolu praktilise keeleõppe jaoks? Ülikoolide keeleõppes pühendatakse mõnevõrra tähelepanu ka keelte ajaloole, aga peale selle puutub keeleõppija kokku soomeugri keelte tüpoloogiaga eriti morfoloogia osas. Tihti rõhutatakse keeleõppes soome-ugri keelte "teistsugusust", kontrasti nende ja (tuntud) indoeuroopa keelte vahel. Selle kontrasti, või üldse soome-ugri keelte "imidži” mõju keeleõppijate motivatsioonile tasuks veel uurida. Tähtis on ka küsimus, kuivõrd soome-ugri keelte õppijad moodustavad "kogukonna" või kas oleks otstarbekam vaadelda neid virtuaalse kogukonnana või “semiootilise ruumina”.

Võtmesõnad: soome-ugri keeled; ajalooline keeleteadus; keeleõpe; keeltesugulus; motivatsioon; õppimise sotsioloogia

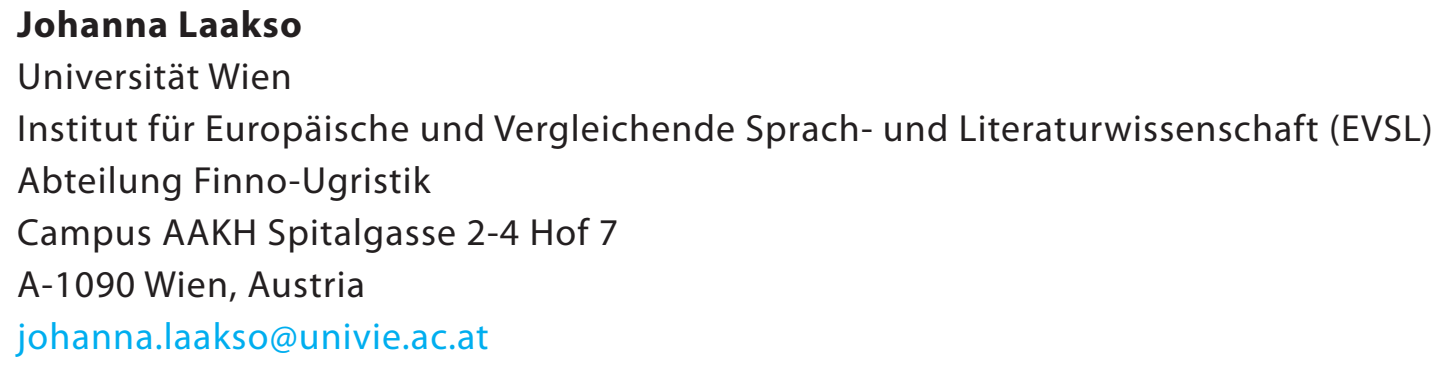

